\title{
Experimental and finite element study of the effect of temperature and moisture on the tangential tensile strength and fracture behavior in timber logs
}

\author{
Larsen, Finn; Ormarsson, Sigurdur
}

Published in:

Holzforschung

Link to article, DOI:

10.1515/hf-2012-0149

Publication date:

2014

Document Version

Publisher's PDF, also known as Version of record

Link back to DTU Orbit

Citation (APA):

Larsen, F., \& Ormarsson, S. (2014). Experimental and finite element study of the effect of temperature and moisture on the tangential tensile strength and fracture behavior in timber logs. Holzforschung, 68(1), 133-140. https://doi.org/10.1515/hf-2012-0149

\section{General rights}

Copyright and moral rights for the publications made accessible in the public portal are retained by the authors and/or other copyright owners and it is a condition of accessing publications that users recognise and abide by the legal requirements associated with these rights.

- Users may download and print one copy of any publication from the public portal for the purpose of private study or research.

- You may not further distribute the material or use it for any profit-making activity or commercial gain

- You may freely distribute the URL identifying the publication in the public portal 


\section{Experimental and finite element study of the effect of temperature and moisture on the tangential tensile strength and fracture behavior in timber logs}

\begin{abstract}
Timber is normally dried by kiln drying, in the course of which moisture-induced stresses and fractures can occur. Cracks occur primarily in the radial direction due to tangential tensile strength (TSt) that exceeds the strength of the material. The present article reports on experiments and numerical simulations by finite element modeling (FEM) concerning the TSt and fracture behavior of Norway spruce under various climatic conditions. Thin log disc specimens were studied to simplify the description of the moisture flow in the samples. The specimens designed for TS were acclimatized to a moisture content (MC) of $18 \%$ before TSt tests at $20^{\circ} \mathrm{C}, 60^{\circ} \mathrm{C}$, and $90^{\circ} \mathrm{C}$ were carried out. The maximum stress results of the disc simulations by FEM were compared with the experimental strength results at the same temperature levels. There is a rather good agreement between the results of modeling and experiments. The results also illustrate the strong decrease of TSt with increasing temperature at a constant MC level.
\end{abstract}

Keywords: cracks, drying of wood, finite element modeling (FEM), moisture content (MC), physical properties of wood, tangential tensile strength

*Corresponding author: Finn Larsen, Department of Civil Engineering, Technical University of Denmark, Brovej, DK-2800 Kgs. Lyngby, Denmark, e-mail: finla@byg.dtu.dk

Sigurdur Ormarsson: Department of Civil Engineering, Technical University of Denmark, Brovej, DK-2800 Kgs. Lyngby, Denmark

\section{Introduction}

Solid timber needs to be dried from a green condition down to a moisture content (MC) below that of the fiber saturation point (FSP) before its utilization as a construction material. When a solid piece of timber board contains both heartwood and sapwood, considerable stresses can develop during drying due to the internal constraints that arise. These stresses can easily exceed the tensile strength of the boards and crack development is the consequence. Scientific and technological efforts to improve drying are as old as wood science, but there are still many challenges as demonstrated by the recent literature. Herritsch and Nijdam (2009) suggested an improved drying model for highly impermeable hardwoods. Junior et al. (2010) reported on nonsymmetrical drying tests for the assessment of drying behavior of a hardwood difficult to dry. Ferrari et al. (2010) and Tomad et al. (2012) measured internal stresses of Radiata pinewood and rubberwood, respectively. Leppänen et al. (2011) studied hardwood drying by X-ray scattering and microtomography. Clair (2012) provided evidence that the release of internal stress contributes to drying strains. Rosner et al. (2012) observed the within-ring movement of free water during drying of Norway spruce. Pearson et al. (2012) reported on the tensile behavior of Radiata pine with different MCs at elevated temperatures. However, the list of recent findings is very long.

Cracks are generally categorized in terms of three major fracture modes, with six possible crack orientations that are possible in relation to the material axis, as pointed out by Smith et al. (2003) and Valentin et al. (1991). Mode I fracture propagation in the TL and TR directions is of major interest in the present study, where $T$, $R$, and $L$ are for tangential, radial, and longitudinal directions, respectively. Mode I fracture means the opening mode, where the tensile stress is normal (perpendicular) to the plane of the crack.

The work is aiming at the determination of the tangential tensile strength (TSt) of Norway spruce and trying to answer the question of how it is affected by the temperature. Two kinds of experiments will be performed: (1) uniaxial tensile strength testing within a climate chamber at $20^{\circ} \mathrm{C}, 60^{\circ} \mathrm{C}$, and $90^{\circ} \mathrm{C}$, while the $\mathrm{MC}$ should be 18\% (Simpson 1973), and (2) kiln drying tests of wood discs at different temperature and humidity levels. It should be observed whether the discs are cracked and how is the crack development in the course of the drying 
process. The experimental disc samples will also be simulated by a 3D distortion model developed by Ormarsson et al. $(1998,1999)$. The crack simulation by finite element modeling (FEM) in the present study is based on description of a cohesive crack model for wood. It is a mode I fracture model, which is verified by fracture tests of wood (Stanzl-Tschegg et al. 1994, 1995; Vasic and Smith 2002; Coureau et al. 2006). The tangential fracture parameters used here are based on experimental studies presented in the literature (Valentin et al. 1991; Reiterer and Sinn 2002; Gustafsson 2003; Smith and Vasic 2003; Vasic and StranzlTschegg 2007; Dourado 2008; Dourado et al. 2008). The expectation is that a conclusive relation can be established between the moisture histories and the shrinkage properties of the samples.

\section{Materials and methods}

The test specimens were selected from 20-year-old Norway spruce trees from North Zealand. The trees were felled in the wintertime in 2009 to 2012; diameters of the logs (free of defects) were 200 to 250 $\mathrm{mm}$. The pieces of logs were kept at approximately $-10^{\circ} \mathrm{C}$ before testing. The specimens were shaped in frozen state to reduce the risk of uncontrolled drying.

The specimens for TSt tests were initially cut in a green condition, each to a size of approximately $18 \times 50 \times 140 \mathrm{~mm}^{3}$. The specimens were then acclimatized in a climate chamber to $18 \% \mathrm{MC}$ at $20^{\circ} \mathrm{C}$ and $85 \%$ relative humidity $(\mathrm{RH})$ before the final shaping was carried out. These climatic conditions were set in accordance with equilibrium MC calculations as given by Simpson (1973). The final dimensions of the bone-shaped samples were $15 \times 40 \times 125 \mathrm{~mm}^{3}$ (see Figure 1). The narrowest area was approximately $15 \times 20 \mathrm{~mm}^{2}$ in size. The exact geometry of each specimen was measured and the specimens were kept in a freezer before testing.

The disc specimens for kiln drying tests were sawn from the log in frozen conditions. The $15 \mathrm{~mm}$ disc thickness is based on the results of Larsen et al. (2010a,b, 2011). The samples were sawn gently by hand to avoid mechanical damages. Sawn disc with defects were discarded.

The TSt tests were performed in the setup presented in Figure 1. As illustrated here, the test frame is outside the climatic chamber, whereas the rods of the sample holder go through moisture-tight rubber bushings on the top and the bottom of the chamber. The loading device is hanging beneath the chamber. This setup makes possible the acclimatization of specimens before testing and to perform the experiments under different climatic conditions. The loading on the specimen was carried out slowly by filling the hanging loading device below the climatic chamber with metal weights until the specimen finally broke. The loading was increased linearly over a period of approximately $5 \mathrm{~min}$. Conditions in the climate chamber: $20^{\circ} \mathrm{C}$ and $86 \% \mathrm{RH}, 60^{\circ} \mathrm{C}$ and $91 \% \mathrm{RH}$, and $90^{\circ} \mathrm{C}$ and $96 \% \mathrm{RH}$.

The log disc experiments, performed in a climate chamber including a digital image correlation (DIC) system (Aramis 2007), are illustrated in Figure 2. The specimen is touching the stand at three individual points and free ventilation around the specimen is afforded. The cameras located outside of the chamber record the deformation of the disc during the drying process. The load cell is connected to a data logger outside the chamber. When the experiments were finished, the dry weight of the specimens was determined after oven drying at $103^{\circ} \mathrm{C}$.

FEM was performed by means of the FE software (Abaqus 2008) based on special routines for wood distortion developed earlier by Ormarsson et al. $(1998,1999)$. The routines take into account that wood is a moisture sensitive (cylindrical) orthotropic material concerning stiffness, shrinkage, and mechanosorption behavior. The stress analysis made use of eight-node linear brick elements of type C3D8. The specimen studied was a circular 15-mm-thick log disc containing 19 annual rings and a pith. The annual rings were divided further into eight parts, each with its own set of material parameters as well as moisture and temperature histories. Four of these parts were assumed to represent thin crack zones having cohesive crack properties, each of the other parts being shaped in the form of a quarter of an annual ring. All annual ring quarters were connected by so-called tie constraints that allowed the log disc to function as an inhomogeneous continuum. The possible crack zones were simulated

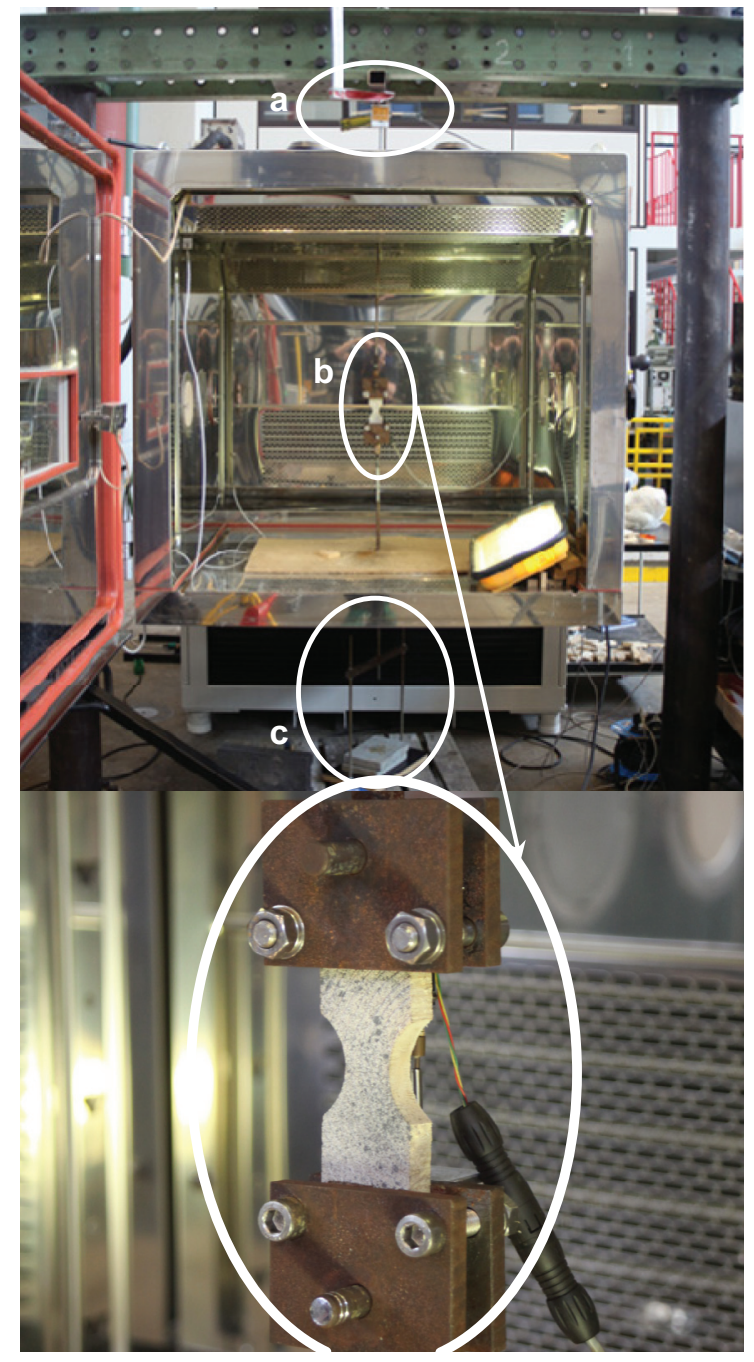

Figure 1 Setup for tensile strength test within the climate chamber: (a) load cell, (b) the specimen together with the clamps, and (c) loading device. 

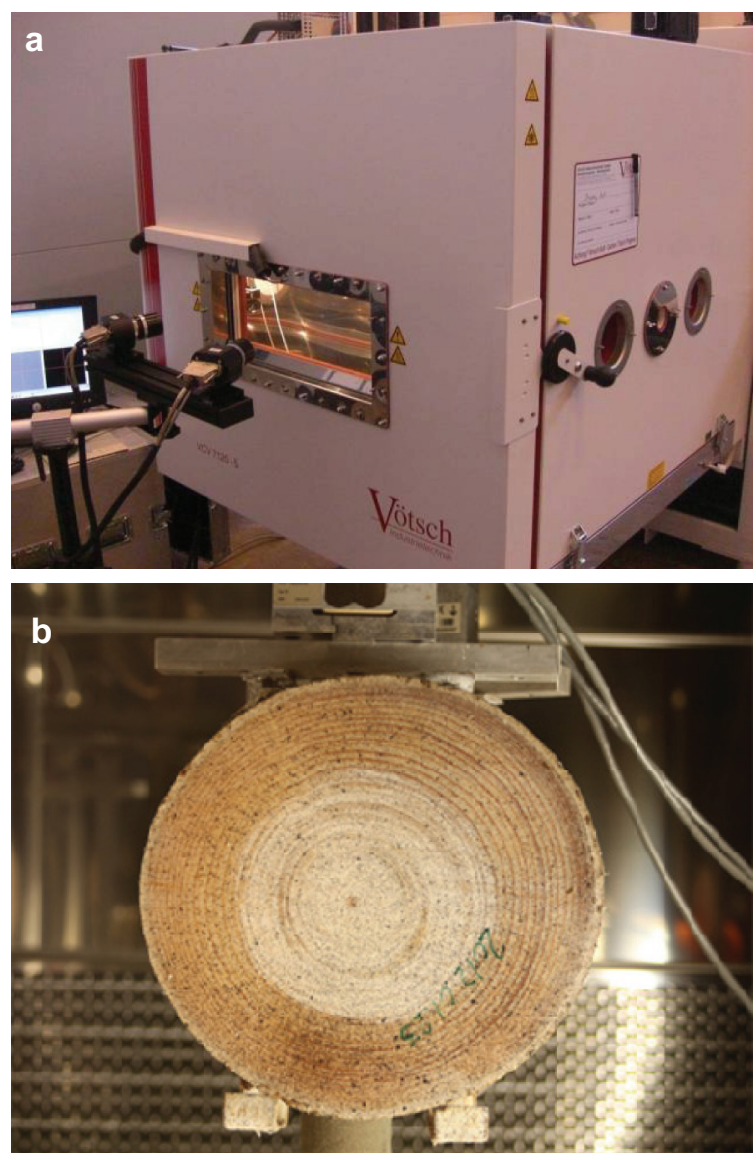

Figure 2 Experimental setup: (a) climate chamber and (b) specimen placed on a specially designed stand and load cell located inside the chamber.

by 0.2-mm-thick cohesive hexahedral elements of type COH3D8 (3D elements). The round disc was created by means of the crack zone parts (orienting horizontally and vertically through the pith) to connect the four disc quarters together (see Figure 3). The disc diameter was with $232 \mathrm{~mm}$ similar to that of the test specimens. Figure 3 shows the mesh of the disc samples studied as well as the locations of the crack zones.

The initial variations in MC (under green conditions) as well as the development of the MC curve over time were obtained along the radius $(r)$ of the discs. Figure 4 shows experimental results for the disc specimens for generating the "moisture history" that was needed as input data for the model. More precisely, a plot was made ("weight changes vs. drying time") and the MC variation is depicted as a function of the segment radius beginning from the pith and ending up at $r=95 \mathrm{~mm}$. The temperature, ventilation around the specimens, and humidity were kept constant during each test.

The parameters needed for FEM - stiffness, mechanosorptive, shrinkage, and temperature parameters typical for Norway spruce of the solid wood material are from Ormarsson et al. (1999) and Larsen and Ormarsson (2012). The radial shrinkage coefficients for heartwood and sapwood obtained in experimental studies were reported by Larsen et al. (2011) and Rosner et al. (2009). The tangential shrinkage coefficient $(\alpha t)$ employed in the present study was assumed to be twice as large as the radial coefficient ( $\alpha r$ ) for the heartwood and the sapwood alike.

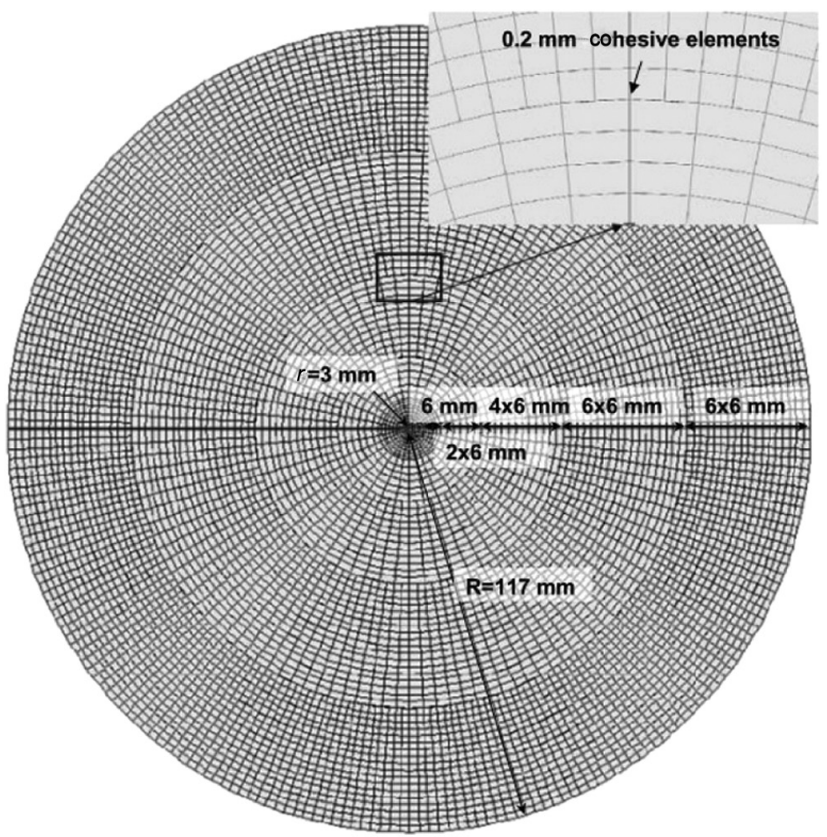

Figure 3 FEM: dimensions of the mesh elements of the disc sample with predefined crack pattern.

The fracture properties of the wood, including fracture energy (GF), the softening curves, and the tensile strength, needed for the cohesive crack simulations, were determined experimentally. Fracture energy (GF) data presented by authors refer to those presented in the introduction and are summarized in Figure 5.

Dourado et al. (2008) and Dourado (2008) reported on the TSt, also mentioned as $\mathrm{ft}$ in the literature, from crack tests of Norway spruce to be 1.66 MPa, whereas Gustafsson (2003) found a value of 3.0 $\mathrm{MPa}$. No such contradictory results were obtained, however, for the $\mathrm{GF}$, for the ratio of microcrack/fiber-bridging energy level, or for its TS. According to Smith and Vasic (2003), the microcrack energy level appears to be appreciably higher than the fiber-bridging energy level. Only a few results are available regarding temperature effects on the fracture properties. In the present FEM simulations, the crack properties were taken from the results presented above (i.e., $\mathrm{GF}=240 \mathrm{~J} \mathrm{~m}^{-2}$ ),

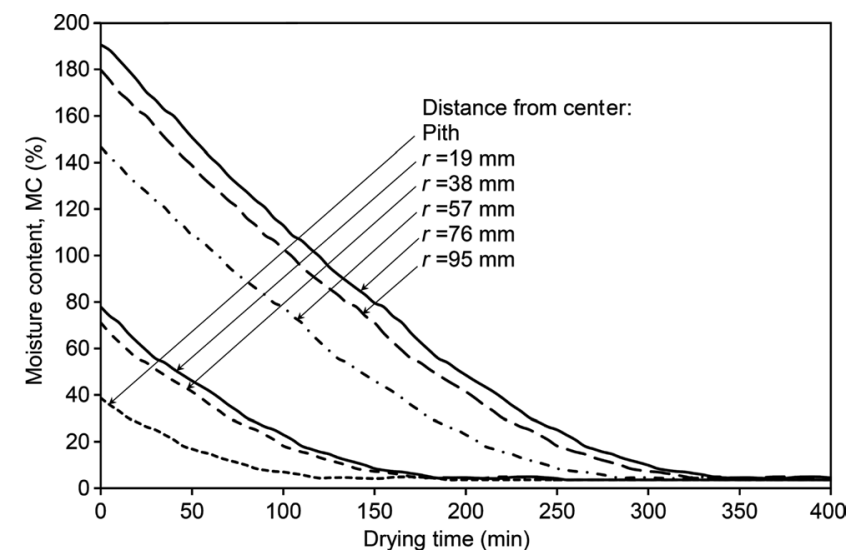

Figure $4 \mathrm{MC}$ histories for the pith and at five different material points along the radius $(r)$ at climatic conditions of $90^{\circ} \mathrm{C}$ and $30 \% \mathrm{RH}$. 


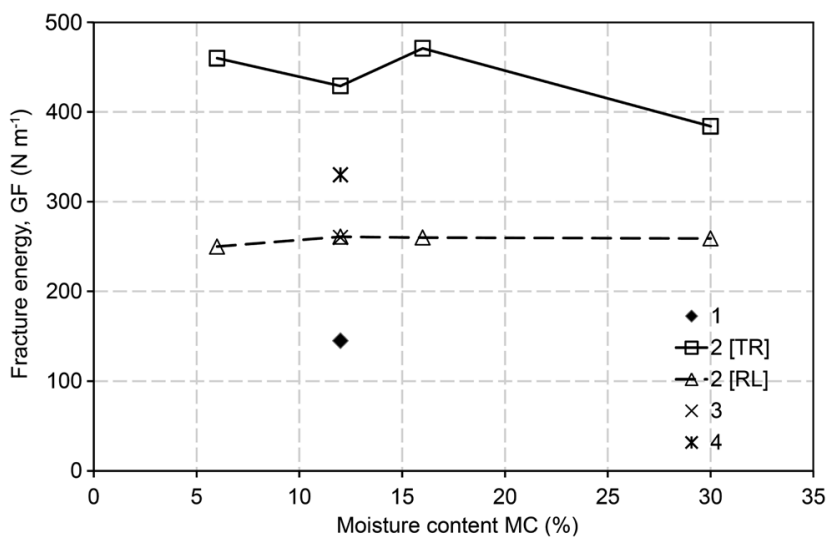

Figure 5 Literature data of the fracture energy (GF) obtained for spruce at $20^{\circ} \mathrm{C}$.

(1) Dourado et al. (2008), (2) Vasic and Stranzl-Tschegg (2007),

(3) Smith et al. (2003), and (4) Gustafsson (2003).

assuming its independence of the temperature; TSt was set to 2.33 MPa based on average value of literature results for Norway spruce at $20^{\circ} \mathrm{C}$. The temperature-related strength reduction is based on the own results reported in this article. According to Smith and Vasic (2003), the fiber-bridging part of the GF is relatively small; therefore, the softening curve was designed as representing the evolution of a linear damage. In the simulations presented here, the following cohesive fracture relations were employed:

$$
\begin{gathered}
\mathrm{GF}=(\mathrm{TSt} \cdot w c) / 2, \\
\mathrm{TS}_{\mathrm{f}, \mathrm{c}}=\mathrm{TSt}-(\mathrm{TSt} 2 w) / 2 \mathrm{GF},
\end{gathered}
$$

where GF is the fracture energy needed for cohesive crack generation, $\mathrm{TS}_{\mathrm{f}, \mathrm{c}}$ is the tangential stress in the crack zone, TSt is the tangential tensile strength of the wood material, $w$ is the crack opening variable in the crack zone, and $w c$ is the limiting value for the crack opening at the ultimate fracture point. Shortly, a linear softening model was applied for the crack generation, instead of a bilinear model, which considers both microcracking and fiber-bridging cracking. Figure 6 shows both linear and bilinear softening behaviors to represent identical

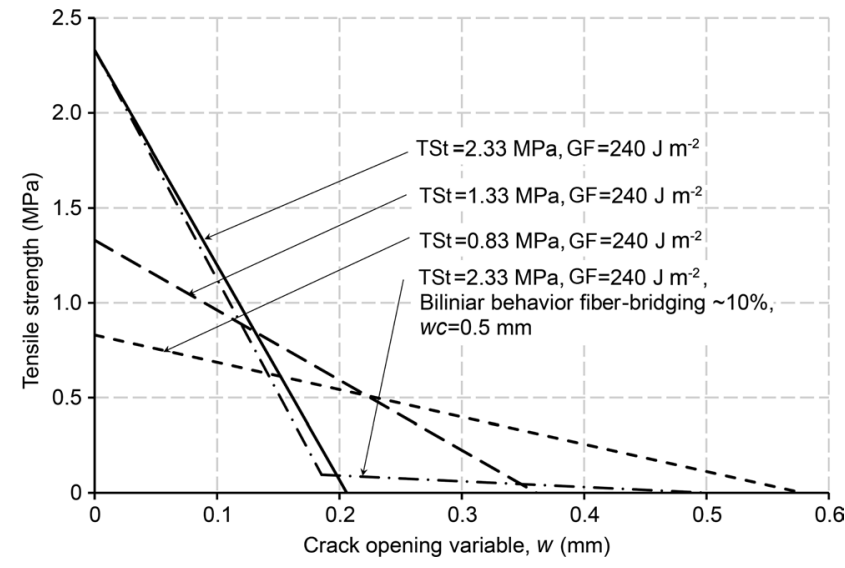

Figure 6 Linear and bilinear softening behaviors at the same level of fracture energy (GF) but with three different tensile strengths. fracture energies but differing TS. It is visible that in the case of the bilinear softening behavior the fiber-bridging part is only $10 \%$ of the total fracture energy (GF). Therefore, both models follow nearly the same path concerning the TS.

\section{Results and discussions}

The TSt decreases with increasing drying temperatures (Table 1).

As pointed out in the experimental procedure, the DIC system according to Aramis (2007) was used to measure the strain, and the changes in weight were logged online from a load cell during the drying process. The system permits the observation whether and at what time point the discs crack. The experimental results concerning the cracked and uncracked samples are shown in the plot "RH\% vs. drying temperature $\left({ }^{\circ} \mathrm{C}\right)$ " in Figure 7.

A straight line with negative inclination separates the fields for cracked and uncracked samples, with the former being beneath and the latter above the line. At low temperatures, the discs crack at a higher level of humidity than they do at higher temperatures. Each sample has its own "moisture history", which means a plot

Table 1 Effects of temperature on the TSt of Norway spruce at $18 \%$ $M C$ in various tests (nos. 1-7).

\begin{tabular}{rrrrrrrrr}
\hline $\boldsymbol{T}\left({ }^{\circ} \mathrm{C}\right)$ & & & & & & & & TSt (MPa) \\
\cline { 2 - 9 } & $\mathbf{1}$ & $\mathbf{2}$ & $\mathbf{3}$ & $\mathbf{4}$ & $\mathbf{5}$ & $\mathbf{6}$ & $\mathbf{7}$ & Average \\
\hline 20 & 2.55 & 2.46 & 2.25 & 2.35 & 2.05 & & & $2.33 \pm 0.20$ \\
60 & 1.14 & 1.58 & 1.39 & 1.73 & 0.75 & 1.27 & 1.47 & $1.33 \pm 0.32$ \\
90 & 1.20 & 0.64 & 0.66 & 0.85 & & & & $0.83 \pm 0.26$ \\
\hline
\end{tabular}

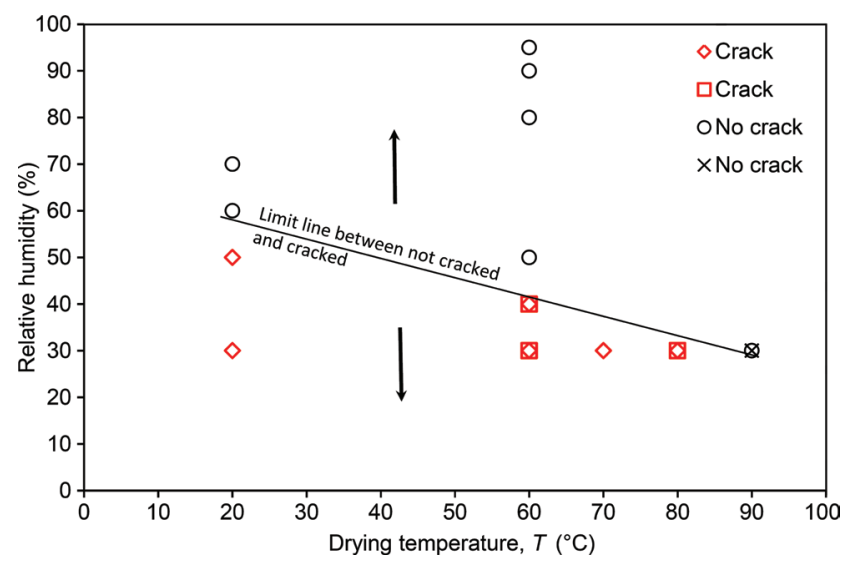

Figure 7 Illustrations of cracked and uncracked disc samples after various drying processes. 
"MC vs. drying time" as a function of the discs radius as presented in Figure 4. Finite element simulations of discs, with moisture histories of each annual ring corresponding to those occurring under each of the climatic conditions close to the crack-limit line, were performed. The TS limit was in the simulations set at a level higher than that of the expected maximum $\mathrm{TS}\left(\mathrm{TS}_{\max }\right.$ ) to determine the areas in which the $\mathrm{TS}_{\max }$ and the related MCs occurred. The climatic condition, the critical TSt $\left(\sigma_{\text {crit }}\right)$ in the transition zone, where cracking begins, is listed in Table 2. The MC values, in the area and at the time when critical TSt occur, are found for each of the simulated discs. The critical TSt found at each disc simulation is compared with the crack or not crack situation found in the experiments (Figure 7).

Table 2 (left-hand side) shows the tendency of lowering $\sigma_{\text {crit }}$ with increasing temperatures, although the stress results in the table cannot be compared with each other directly because of their different MC values. Siimes (1967) found (quoted from Gustafsson 2003) that TSt decreases with increasing temperature and MC (Figure 8). An exception is spruce wood, when TSt is elevated when the temperature rises from $20^{\circ} \mathrm{C}$ to $40^{\circ} \mathrm{C}$.

The stresses have been adjusted to a MC of $18 \%$ (Table 2, right-hand side) based on the results presented in Figure 8. The values in question were evaluated further to determine the TS values for each temperature at which cracks could develop. These are somewhere in between the simulated stress values for cracked and uncracked discs. The values in Figure 9 with circular markers are from Table 2 and the crosses are TSt data from Table 1. The dashed line in Figure 9 represents the trend line for TSt obtained experimentally.

The critical TSt values are compared with the results of the tests of TSt presented in Table 1. The plots in Figure 9 indicate a close correlation between the critical stresses $\left(\sigma_{\text {crit }}\right)$ and the measured strengths, although the two trend lines are slightly displaced. An equation describing the relationship between TSt and temperature $T$ is

$$
\text { TSt, } T=\mathrm{TSt}, 20^{\circ}(1.188-0.0092 \cdot T) \text {, }
$$

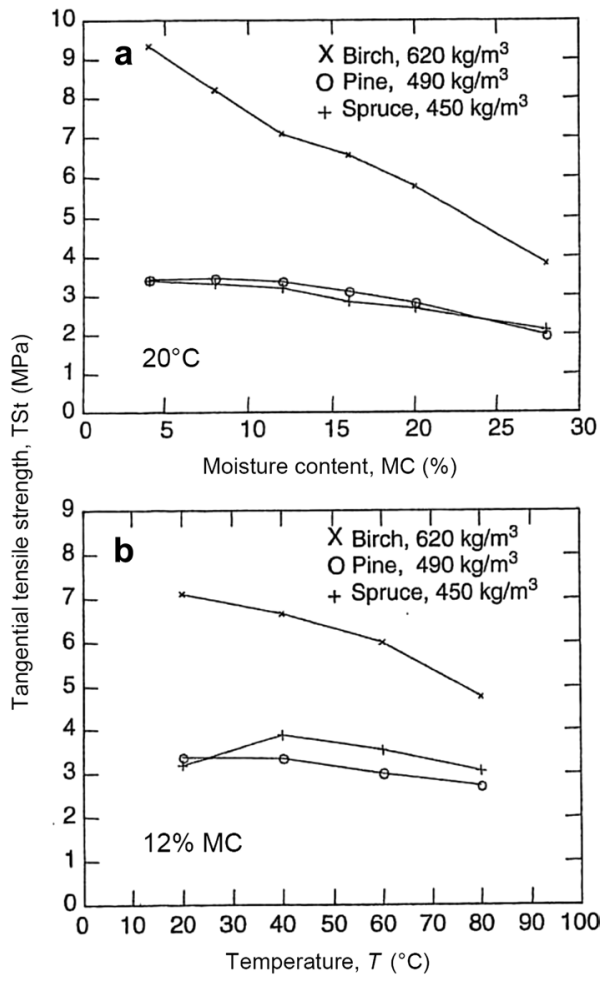

Figure 8 Data of Gustafsson (2003). Dependence the TSt on temperature and on MC.

where TSt, $T$ is the TSt at the fixed temperature indicated at $18 \% \mathrm{MC}$, and TSt, $20^{\circ}$ is the reference tangential strength at $20^{\circ} \mathrm{C}$. In Figure 9, the parameter TSt, $20^{\circ}$ is set to $2.4 \mathrm{MPa}$. The effect of MC on the strength was not evaluated in the present study, but according to Figure 8 the strength of the wood is highly dependent on the MC level.

Both simulated and experimentally obtained results show clearly that the temperature has a marked effect on the TSt. This dependency found in the present article is more pronounced than reported for Norway spruce in the literature. The MC in Figure 8 is $12 \%$, whereas the MC in Figure 9 is $18 \%$. Whether this difference in MC has any effect on the temperature-related strength reduction would deserve a special test series. The same is true for

Table 2 Simulated critical TSt in the transition zone under different climatic conditions and at $18 \%$ MC.

\begin{tabular}{|c|c|c|c|c|c|c|}
\hline \multirow[t]{2}{*}{$T\left({ }^{\circ} \mathrm{C}\right)$} & \multirow[t]{2}{*}{ RH (\%) } & \multicolumn{3}{|r|}{ At various MCs } & \multicolumn{2}{|c|}{ At $18 \% \mathrm{MC}$} \\
\hline & & $\sigma_{\text {crit }}(\mathrm{MPa})$ & MC (\%) & Crack (yes/no) & $\sigma_{\text {crit }}(\mathrm{MPa})$ & MC (\%) \\
\hline 20 & 50 & 2.50 & 23.0 & Yes & 3.03 & 18.0 \\
\hline 20 & 60 & 2.11 & 19.0 & No & 2.19 & 18.0 \\
\hline 60 & 40 & 1.69 & 20.0 & Yes & 2.05 & 18.0 \\
\hline 60 & 50 & 1.68 & 14.5 & No & 1.42 & 18.0 \\
\hline 80 & 30 & 1.26 & 18.5 & Yes & 1.30 & 18.0 \\
\hline 90 & 30 & 1.65 & 9.0 & No & 1.01 & 18.0 \\
\hline
\end{tabular}




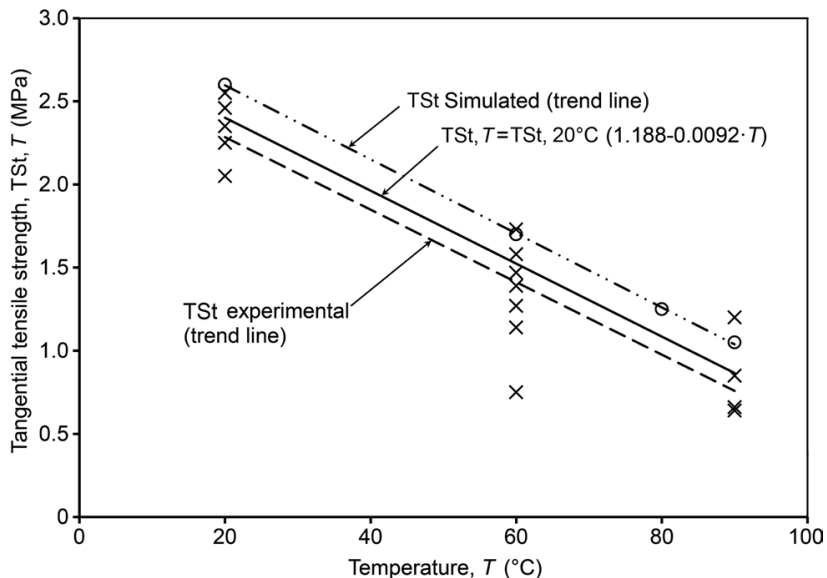

Figure 9 Effect of the temperature on the TSt as estimated from tests and from disc simulations at $18 \%$ MC.

the temperature-strength relationship for the radial and longitudinal directions.

FEM(cracksimulation)wasperformedonthediscsbased on the TS and on the fractureenergy (GF) as described above. These data are considered as the primary cohesive crack properties. The crack development was followed and compared with pictures generated by the Aramis (2007) equipment at selected points in time during the drying process. The fracture model based on Equations (1) and (2) was implemented in the model. The disc simulation presented in Figure 10 is for drying at $20^{\circ} \mathrm{C}$ and $30 \%$ RH. Results of the simulation are compared with disc drying experiments exposed to the same climatic conditions. Figure 10 shows both simulated and experimentally observed crack patterns at four different times during the drying process.

A close agreement can be stated between the simulated crack development and the experimental results. The stress situation after $9 \mathrm{~h}$ of drying, when only the heartwood was dried just below FSP, reveals a crack in the heartwood that developed shortly before this state had been reached. The heartwood area was geometrically fixed by the surrounding sapwood, which led to an increase of stress when the heartwood shrank. The crack generation that occurred released some of the TS in the heartwood zone, whereas marked tensile and compressive stresses accumulated in the transition zone. The stress situation after $12.5 \mathrm{~h}$ of drying, when a large part of the transition zone was dried to a MC below FSP, shows the TS having been reduced and the zone of large tensile and compressive stresses having moved further toward the sapwood. The final stress situation after $25 \mathrm{~h}$ of drying shows marked compression stresses that had been built up in the outer zone of the heartwood area due to the shrinkage of the sapwood area.
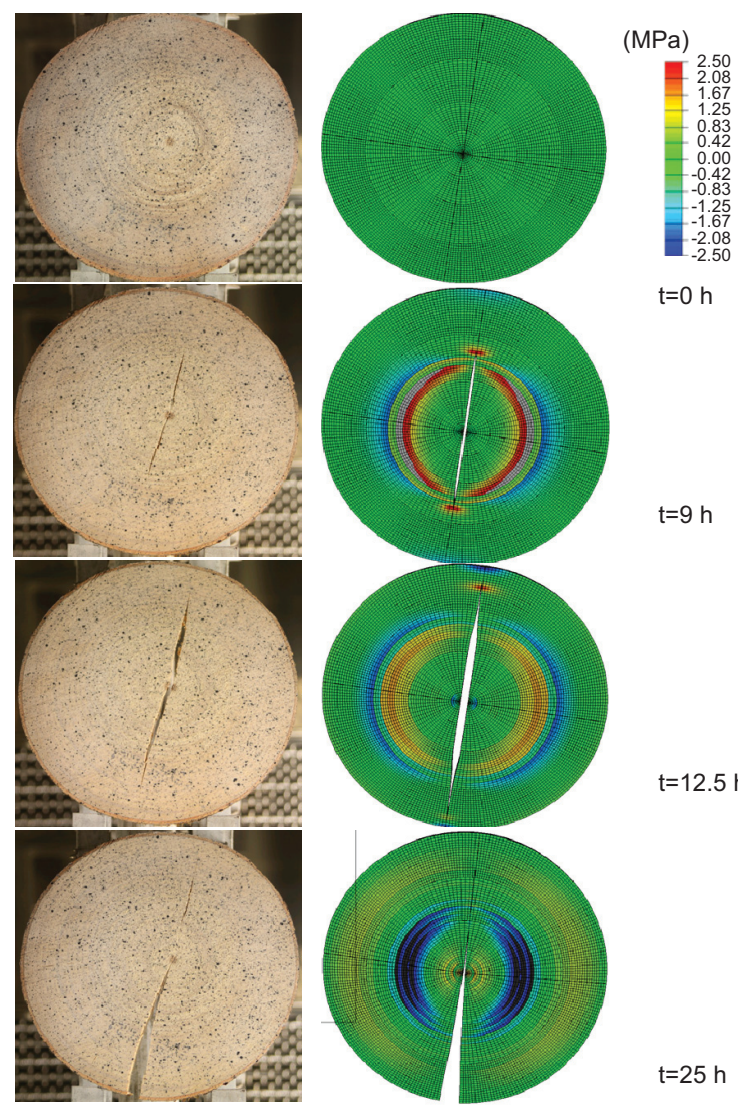

Figure 10 Experimentally observed and FEM-simulated crack patterns, together with variations in tangential stress in a disc sample at different times of the drying process (conditions: $20^{\circ} \mathrm{C}$ and $30 \% \mathrm{RH}$ ).

\section{Conclusion}

The temperature has a marked influence on the TSt of Norway spruce samples. For constant MC condition, TSt was markedly decreasing in a linear fashion with increasing temperature. This conclusion is based on the presented test results performed under well-defined climate conditions, giving $18 \% \mathrm{MC}$ in the test samples, regardless of the temperature level. These strength results were confirmed both by well-defined drying experiments of thin log discs and by advanced finite element simulations of the same discs. The close agreement of these methods could be seen as rather clear verification of the simulation model.

Based on available data for cohesive crack model for Norway spruce, the developed simulation model was able to simulate the whole crack propagation that took place in the disc samples studied, when they were exposed to different drying schedules. The examples presented in Figure 10 illustrate rather well the close correlation found between experimentally observed and FEM-simulated 
crack patterns during the drying process as a whole. Only limited results are available concerning the effects of MC on the tangential and radial tensile strength of wood. Knowledge of the latter is of considerable importance in analyzing crack developments during kiln drying of wood. These questions are still waiting for detailed investigation in terms of fracture energy (GF) under different climatic conditions. The stress development during the kiln drying of timber boards should also be studied over cross-sections of the boards.

Acknowledgements: Funding: The Danish Forest and Nature Agency, Haraldsgade 51, 2100 København $\emptyset$.

Received September 17, 2012; accepted March 14, 2013; previously published online June 12, 2013

\section{References}

Abaqus. Theory Manual v6.8. Simulia, Dassault Systems Simulia Corp., Providence, RI, USA, 2008.

Aramis v6 User Manual, GOM mbH, GOM Optical Measuring Techniques, Mittelweg 7-8, D-38106 Braunschweig, Germany, 2007.

Clair, B. (2012) Evidence that release of internal stress contributes to drying strains of wood. Holzforschung 66:349-353.

Coureau, J.L., Morel, S., Gustafsson, P.J. (2006) Influence of the fracture softening behaviour of wood on load-COD curve and R-curve. Mater. Struct. 40:97-106.

Dourado, N. R-curve behaviour and size effect of a quasibrittle material: wood. Ph.D. thesis. $\mathrm{N}^{\circ}$ d'ordre: 3734 . L'Université Bordeaux I, France, 2008.

Dourado, N., Morel, S., de Moura, M.F.S.F., Valentin, G., Morais, J. (2008) Comparison of fracture properties of two wood species through cohesive crack simulations. Composites Part A 39:415-427.

Ferrari, S., Pearson, H., Allegretti, O., Gabbitas, B. (2010) Measurement of internal stress in Radiata pine sapwood. during drying using an improved online sensor. Holzforschung 64:781-789.

Gustafsson, P.J. Timber Engineering. John Wiley \& Sons Ltd., West Sussex, England, 2003, pp. 103-130, ISBN 0-470-48869-8.

Herritsch, A., Nijdam, J.J. (2009) An improved drying model.. for highly-impermeable hardwoods. Holzforschung 63: 464-471.

Junior, E.U., Allegretti, O., Terziev, N., Söderström, O. (2010) Application of non-symmetrical drying tests for assessment of drying behaviour of ntholo (Pseudolachnostylis maprounaefolia PAX). Holzforschung 64:363-368.

Larsen, F., Ormarsson, S. (2012) Numerical and experimental study of moisture-induced stress and strain field developments in timber logs. Wood Sci. Technol. Published online April 2013.

Larsen, F., Ormarsson, S., Olesen, J.F. Proceedings of the 11th International IUFRO Wood Drying Conference, Luleå University of Technology, Skellefteå, Sweden, 2010a, pp. 137-144.

Larsen, F., Ormarsson, S., Olesen, J.F. Proceedings of the 11th World Conference on Timber Engineering, Riva del Garda, Italy, 2010b, pp. 449-451.

Larsen, F., Ormarsson, S., Olesen, J.F. (2011) Moisture-driven fracture in solid wood. Wood Mater. Sci. Eng. 6:49-57.

Leppänen, K., Bjurhager, I., Peura, M., Kallonen, A., Suuronen, J.-P., Penttilä, P., Love, J., Fagerstedt, K., Serimaa, R. (2011) X-ray scattering and microtomography study on the structural changes of never-dried silver birch, European aspen and hybrid aspen during drying. Holzforschung 65:865-873.
Ormarsson, S., Dahlblom, O., Petersson, H. (1998) A numerical study of the shape stability of sawn timber subjected to moisture variation. Part 1: theory. Wood Sci. Technol. 32:325-334.

Ormarsson, S., Dahlblom, O., Petersson, H. (1999) A numerical study of the shape stability of sawn timber subjected to moisture variation. Part 2: simulation of drying board. Wood Sci. Technol. 33:407-423.

Pearson, H., Gabbitas, B., Ormarsson, S. (2012) Tensile behaviour of Radiata pine with different moisture contents at elevated. temperatures. Holzforschung 66:659-665.

Reiterer, A., Sinn, G. (2002) Fracture behaviour of modified spruce wood: a study using linear and non linear fracture mechanics. Holzforschung 56:191-198.

Rosner, S., Karlsson, B., Konnerth, J., Hansmann, C. (2009) Shrinkage processes in standard-size Norway spruce wood specimens with different vulnerability to cavitation. Tree Physiol. 29:1419-1431.

Rosner, S., Riegler, M., Vontobel, P., Mannes, D., Lehmann, E.H., Karlsson, B., Hansmann, C. (2012) Within-ring movement of free water in dehydrating Norway spruce sapwood visualized. by neutron radiography. Holzforschung 66:751-756.

Siimes, F.E. The effect of specific gravity, moisture content, temperature and heating time on the tension and compression strength and elasticity properties perpendicular to the grain of Finnish pine, spruce and birch wood and the significance of these factors on the checking of timber at kiln drying. Julkaisu 84 publication, VTT - The technical research centre of Finland, 1967.

Simpson, W.T. (1973) Predicting equilibrium moisture content of wood by mathematical models. Wood Fiber Sci. 5: 41-49.

Smith, I., Vasic, S. (2003) Fracture behaviour of softwood. Mech. Mater. 35:803-815.

Smith, I., Landis, E., Gong, M. Fracture and Fatique in Wood, Wiley, West Sussex, England, 2003. ISBN 0-471-48708.

Stanzl-Tschegg, S.E., Tschegg, E.K., Teischinger, A. (1994) Fracture energy of spruce wood after different drying procedures. Wood Fiber Sci. 26:467-478.

Stanzl-Tschegg, S.E., Tan, D.M., Tschegg, E.K. (1995) New splitting method for wood fracture characterization. Wood Sci. Technol. 29:31-50.

Tomad, S., Matan, N., Diawanich, P., Kyokong, B. (2012) Internal stress measurement during drying of rubberwood lumber: effects of wet-bulb temperature in various drying strategies. Holzforschung 66:645-654. 
Valentin, G.H., Boström, L., Gustafsson, P.J., Ranta-Maunus, A., Gowda, S. Application of fracture mechanics to timber structures RILEM state-of-the-art report, Statens tekniska forskningscentral, Technical Research Centre of Finland, Research Notes 1262, Espoo, Finland, 1991.
Vasic, S., Smith, I. (2002) Bridging crack model for fracture of spruce. Eng. Fract. Mech. 69:745-760.

Vasic, S., Stranzl-Tschegg, S. (2007) Experimental and numerical investigation of wood fracture mechanisms at different humidity levels. Holzforschung 61:367-374. 